\title{
LANGUAGE BEUEFS AMONG ADULT LEARNERS: INDIVIDUAL DIFFERENCES
}

\author{
Aiza Johari*, Siti Huzaimah Sahari, Affidah Morni \& Amelia Alfred Tom \\ Universiti Teknologi MARA, Sarawak Branch, Malaysia \\ *aiza@sarawak.uitm.edu.my
}

First draft received: 31 July 2017

Final proof received: 27 August 2017

\begin{abstract}
To develop the quality of language learning and utilise learning opportunities in and out of a classroom, it is vital to understand individual's beliefs in language learning. White (2008) affirmed that an individual's belief plays a key role in the learning process and language acquisition, especially the beliefs the learners have about themselves, language and language learning, and about the settings in which they contribute as language learners and users. This study identifies the English language learning beliefs of adult learners (between 45-50 years of age) in a local university in Sarawak. Questionnaire was the instrument to collect the data, and the data were analysed using SPSS Version 21. The study showed that these adult learners have various levels of language beliefs. The results obtained can be used to enhance the teaching and learning of English language where language instructors can learn more about their learners and the learners' language beliefs can further enhance learning process in the classroom.
\end{abstract}

Keywords: Language beliefs; individual differences; adult learners.

To cite this paper (in APA style):

Johari, A., Sahari, S. H., Morni, A., \& Tom, A. A. (2017). Language beliefs among adult learners: Individual differences. International Journal of Education, 10 (1), 20-25. doi: http://dx.doi.org/10.17509/ije.v10i1.7648

\section{INTRODUCTION}

Many people may find learning a foreign or second language to be challenging and daunting, and this scenario exists among Malaysian learners of English language. In Malaysia, English plays a role as the second language in which English language is taught in school education system because English is significant in the students' daily lives and future career. Smith and Strong (2009) mentioned that at present, World English being an international language is of increasing importance in international communication, business, media and pop culture as well as in research journals and in such field like the civil aviation. Many Malaysians often speak English in business, government offices, workplace, higher learning institutions and public places such as the banks, billing counters and even markets. As a result, though English is not the official language, it has become crucial for Malaysians to be able to communicate in English, whether at an average or mastery level.

However, Hariati and Lee (2011) affirmed that many educators grumble on the declining levels of English performance and proficiency among students in schools and universities. To add, Zuraidah (2007) observed that many English learners tend to exhibit reluctance and seem hesitant to speak out unless it is absolutely necessary. Consequently, many English learners in Malaysia perceive English learning as challenging, even before they step into the classroom. Due to such belief, they struggle to master the language. To make the matter worse, some lack motivation, thus affecting their efforts to commit. Moreover, Chew and Chui (2012) pointed out that taking into account of the learner's role in the learning process might be uncommon in Malaysia, unlike the western countries which place more importance on the significant roles of the learners in the learning process.

In order to achieve their goals in learning languages, learners need to have positive beliefs, motivation and self-confidence. Fazilatfar et al. (2015) considered beliefs as cognitive entities that guide humans to behave in a community. They are crucial factors that lead most human behavior. Hence, Woolfolk (2006) affirmed that the learners' beliefs and attributions do give a significant impact to the learners' drive to learn any language. In addition, Kalaja and Barcelos (2003) defined language belief as a particular area of an individual's learner difference which may influence the acquisition of foreign or second language learning, mainly their learning experiences. Notably, White (2008) affirmed that beliefs play a significant role in the learning process and "in terms of language learning, the domains of beliefs which are acknowledged as relevant are the beliefs learners hold about themselves, about language and language learning, and about the contexts in which they 
participate as language learners and language users" (p.121). Horwitz (1988), the first researcher who conducted a detailed research into beliefs in language learning, has developed the Beliefs about Language Learning Inventory (BALLI) to access language learners' beliefs about language learning. She perceived that such beliefs are influencing language learners' expectations, motivation, and commitment to language learning.

Ellis (2008) further asserted that learners' beliefs are present when they have recognised several attributes of language learning and language learning ability such as knowledge of the target language, strategies, goals and cultural influences. Therefore, it is significant for educators to understand their learners' beliefs as what the learners bring into the classroom may influence their actions and affect how they learn in the classroom. If language educators acknowledge these various beliefs, the teaching techniques can be improved to suit the existing learners' beliefs. Hence, they provide more effective teaching and learning process. Moreover, Talebinejad and Nekauei (2013) observed that over the last three decades, there has been a change in second language acquisition from teaching methods to learner characteristics, in which much of the responsibility for success in language learning depends highly on the effort of individual learners.

Accordingly, English language education has also been emphasised of greater importance in adult education (Smith and Strong, 2009). Adult language learners may devise various language learning perspectives and objectives. Merritt (2013) mentioned that many adults, in fits of frustration, will claim that adults are simply poor at languages as children have more porous minds, better memories, and adaptability. Nevertheless, Merritt further reported that linguistic researchers have found that this claim to be a myth where under controlled conditions, adults can be better at language learning. To add, Smith and Strong (2009) affirmed that most adult learners are goal -oriented and often direct their learning to fulfil particular needs (to advance their studies, progress their career ladder, follow business opportunities, assist children with homework, or simply to be successful users of the language) in which adults can usually communicate effectively in their first language and may code switch between several other languages. Robinson (2005) also discovered that adult learners have greater cognitive and linguistic capabilities, and conceptual complexity than younger learners. As a consequence, it is interesting to investigate whether adult learners have different language beliefs that may influence the way they learn and master English language or other foreign languages. As recommended by Smith and Strong (2013) innovative teaching in an adult classroom can integrate stimulating and enjoyable tasks in providing elements of engagement, collaboration, investigation, and critical analysis of content, context, culture, and structures.
In addressing individual differences in adults' English learning, adult second language learning traditionally involves individual differences such as aptitude, motivation, learning strategies, learning styles, meta-linguistic awareness, and personality traits (e.g., extraversion), as well as a range of other social and affective variables (Ehrman, Leaver \& Oxford, 2003). Consequently, adult learners generally embrace a wide range of variables: age, gender, intelligence, personality, learning style and previous learning experience, in which also include their own individual beliefs, attitudes, expectations, motivations and strategies (Hurd, 2006). As a result, educators need to be aware of these variables and provide authentic language activities that can cater to these variables, in which a learner is likely to react, respond and reflect differently to the learning materials.

\section{RESEARCH PURPOSE AND RESEARCH QUESTIONS}

The purpose of this study is to investigate language learners' beliefs specifically on English or foreign language learning among a group of adult learners in one of the local universities in Sarawak. To investigate the learners' beliefs, the items in the questionnaires have been categorised into five major scopes: Foreign Language Aptitude (items 1 to 9), Difficulty of Language Learning (items 10 to 15), Nature of Language Learning (items 16 to 22), Learning and Communication Strategies (items 23 to 31 ), and Motivations and Expectations (items 32 to 39 ). The research questions are:

1. What are the beliefs of ESL adult learners on foreign language aptitude?

2. What are the beliefs of ESL adult learners on the level of difficulty in ESL learning?

3. What are the beliefs of ESL adult learners on the nature of ESL learning?

4. What are the beliefs of ESL adult learners on the learning and communication strategies?

5. What are the beliefs of ESL adult learners on motivations and expectations in ESL learning?

\section{RESEARCH METHODOLOGY}

The respondents of this study comprised sixteen adult ESL learners (aged 45-50 years old) who did their part time studies in the respective university. They are working adults who represented the urban and rural areas in Sarawak. This was a quantitative study and the questionnaire was adapted from Horwitz's BALLI (1988) and Vilbulphol (2004). Notably, slight changes were made to suit the context of the present study. There are 39 items in the survey form and the items are to be answered on a five-point Likert-type scale, with options from strongly agree, agree, neutral, disagree to strongly disagree. The data collected were then analysed using SPSS 21 and presented in tabular forms, in accordance to mean scores and highest frequencies (percentages). 


\section{ANALYSIS AND DISCUSSION}

Firstly, the demographic data of the respondents are presented. Most of the respondents are males (only three females among the sixteen respondents) and many of them are in the early fifties. In terms of ethnic population, majority are Malays (56\%) while the rests are Iban, Bidayuh, Kedayan and Melanau. Their SPM English Paper Grades are on the average level in which many of them scored between Grade 3 to Grade 6 .

Table 1: Language Beliefs (Foreign Language Learning/ Aptitude)

\begin{tabular}{|c|c|c|c|}
\hline Items & Mean & $\begin{array}{l}\text { Std. } \\
\text { Deviation }\end{array}$ & $\begin{array}{c}\text { Highest } \\
\text { Frequencies }\end{array}$ \\
\hline 1. It is easier for children than adults to learn a foreign language & 4.00 & 1.095 & A 56\%/S.A 31\% \\
\hline $\begin{array}{l}\text { 2. Some people have a special ability in learning foreign languages } \\
\text { such as English }\end{array}$ & 4.44 & .629 & S.A $50 \% /$ A $44 \%$ \\
\hline 3. Malaysians are good at learning foreign languages. & 3.88 & .806 & $\mathrm{~N} / \mathrm{A} 38 \%$ \\
\hline $\begin{array}{l}\text { 4. It is easier for someone who already speaks a foreign language to } \\
\text { learn another one. }\end{array}$ & 3.56 & 629 & A $56 \%$ \\
\hline $\begin{array}{l}\text { 5. People who are good at Mathematics or Science are not good at } \\
\text { learning foreign languages. }\end{array}$ & 2.69 & 1.250 & N 38\% / S.D 25\% \\
\hline 6. I have a special ability in learning foreign languages. & 3.56 & .629 & N 50\%/ A 44\% \\
\hline 7. Women are better than men in learning foreign languages. & 2.88 & 1.025 & $\mathrm{~N} 38 \% / \mathrm{A} 31 \%$ \\
\hline 8. People who speak more than one language are intelligent. & 3.88 & .885 & A $44 \%$ \\
\hline 9. Everybody can learn to speak a foreign language. & 3.87 & .619 & A $63 \%$ \\
\hline
\end{tabular}

${ }^{*}$ S.A- Strongly agree; A-agree; N- neutral; D- disagree; S.D- strongly disagree

Table 1.0 shows the issue of the learner's potential to be successful in learning a language with regards to their beliefs to foreign language learning or aptitude. Majority of the respondents agreed and strongly agreed that age can affect a learner's proficiency to learn a language and this result is congruent to the common claim made by most adults in Merritt's study (2012) in which adults are believed to be simply poor at language compared to children who seem to have better language learning capabilities. Besides, some of the respondents also admitted that they possessed special ability to learn foreign language (44\% agreed). This is a positive note as they seemed to be able to utilize their learning capabilities to master a language. Some of the noteworthy findings are $44 \%$ agreed that people who are bilingual are considered as intelligent while more than half of the respondents acknowledged that everyone can speak a foreign language if given the opportunity.

Table 2: Language Beliefs (Level of Difficulty in ESL Learning)

\begin{tabular}{|c|c|c|c|}
\hline Items & Mean & $\begin{array}{l}\text { Std. } \\
\text { Deviation }\end{array}$ & $\begin{array}{c}\text { Highest } \\
\text { Frequencies }\end{array}$ \\
\hline 10. Some languages are easier to learn than others & 3.94 & .574 & A $69 \%$ \\
\hline 11. I believe that I will learn to speak English well. & 4.19 & .544 & A $69 \%$ \\
\hline $\begin{array}{l}\text { 12. In learning English, it is easier to speak up than to understand } \\
\text { what people say. }\end{array}$ & 3.44 & .964 & A $56 \%$ \\
\hline 13. In learning English, reading is easier than speaking and listening. & 3.63 & .957 & A $56 \%$ \\
\hline 14. In learning English, writing is easier than speaking and listening. & 3.37 & .957 & A $50 \%$ \\
\hline $\begin{array}{l}\text { 15. People whose first language use a different alphabet system than } \\
\text { English will find it difficult to learn English. }\end{array}$ & 3.56 & .892 & A $56 \%$ \\
\hline
\end{tabular}

${ }^{\star}$ S.A- Strongly agree; A-agree; N- neutral; D- disagree; S.D- strongly disagree

All the items in Table 2 show the learner's beliefs in relation to the level of difficulty in ESL learning. It is interesting to note that most of the items reported the mean scores of 3.5 and above ('agreement' with the percentages between $50 \%$ to $70 \%$ ). It is perceived that the respondents agreed that some languages are easier to learn than the others. They seemed to be positive about it as they believed that they can learn to speak English well. Such positive beliefs can affect their motivation and confidence in learning process and this is supported by Dornyei (2005) who stated that beliefs could be useful for practical reasons in which educators can help to develop these beliefs to enhance learning. On a lesser note, these admissions of finding reading and writing skills less difficult than the other skills (speaking and listening) might also indicate that some respondents lacked confidence of speaking in English or any other foreign languages and thus, they might feel shy or face difficulties in communicating in other languages besides their own mother tongue. The ability to obtain and master all four language skills is a merit if one desires to be an effective English speaker. On another note, adult 
learners usually have diverse variables when it comes to learning English which include individual beliefs, attitudes, expectations, motivations and strategies (Hurd, 2006). Thus, if the respondents obtain certain degree of positive beliefs in learning English language, they are able to overcome their individual differences to adapt to the given language activities and complete the tasks effectively. Educators on the other hand, need to adjust their language lessons and activities to suit the needs of their learners, both in terms of the syllabus and learner differences.

Table 3: Language Beliefs (Nature of Language Learning)

\begin{tabular}{|c|c|c|c|}
\hline Items & Mean & $\begin{array}{l}\text { Std. } \\
\text { Deviation }\end{array}$ & \\
\hline $\begin{array}{l}\text { 16. It is necessary to know the customs, the cultures, and the } \\
\text { lifestyles of English speaking people (such as British, Americans or } \\
\text { Australians) in order to speak English correctly and appropriately in a } \\
\text { particular context. }\end{array}$ & 3.31 & 1.014 & $\mathrm{~N} / \mathrm{A} 31 \%$ \\
\hline $\begin{array}{l}\text { 17. It is best to learn English in an English-speaking country such as } \\
\text { England, United States or Australia. }\end{array}$ & 3.88 & .957 & A $63 \%$ \\
\hline 18. Learning vocabulary is an important part of learning English. & & .479 & A 69\% / S.A. 31 \\
\hline 19. Learning grammar is an important part of learning English. & & .479 & A $69 \% /$ S.A. 31 \\
\hline $\begin{array}{l}\text { 20. Learning how to translate directly from Bahasa Malaysia is an } \\
\text { important part of learning English. }\end{array}$ & 3.75 & .775 & A $56 \%$ \\
\hline $\begin{array}{l}\text { 21. Learning English is different from learning other academic } \\
\text { subjects. }\end{array}$ & 3.56 & .892 & A $56 \%$ \\
\hline \multicolumn{2}{|l|}{$\begin{array}{l}\text { 22. Learning English involves a lot of memorization. } \\
\text { S.A- Strongly agree; A-agree; } N \text { - neutral; D- disagree; S.D- strongly disagree }\end{array}$} & 1.000 & A $50 \%$ \\
\hline \multicolumn{4}{|c|}{ 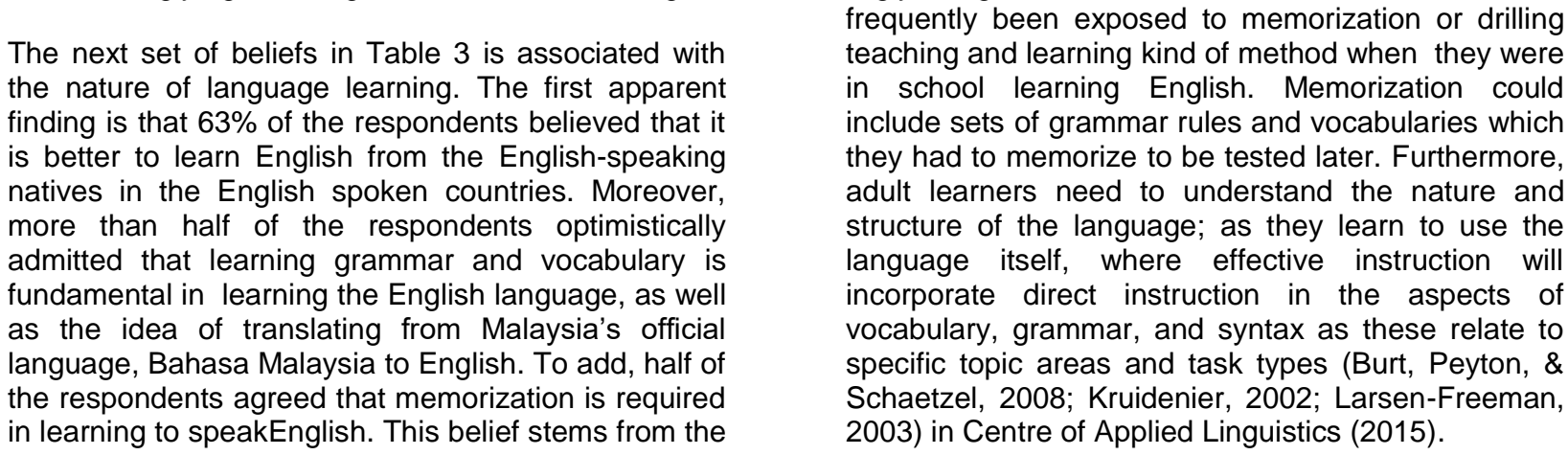 } \\
\hline
\end{tabular}
fact that these respondents, who are also adult learners, are probably 'old-timers' who might have

Table 4: Language Beliefs (Learning and Communication Strategies

\begin{tabular}{|c|c|c|c|}
\hline Items & Mean & Std. Deviation & $\begin{array}{c}\text { Highest } \\
\text { Frequencies }\end{array}$ \\
\hline 23. It is important to speak English with correct pronunciation. & 3.69 & .793 & A $69 \%$ \\
\hline 24. We shouldn't say anything in English until we can say it correctly. & 3.44 & 1.209 & $\begin{array}{l}\text { A } 44 \% / D \\
38 \%\end{array}$ \\
\hline 25. I enjoy practising English with the foreigners I meet. & 3.81 & .655 & A $56 \%$ \\
\hline 26. It is okay. to guess, if we don't know a word in English. & 3.27 & 1.062 & A $44 \%$ \\
\hline 27. In learning English, it is important to practise a lot. & 4.31 & .602 & A $56 \%$ \\
\hline 28. I feel timid (shy) speaking English with other people. & 3.19 & 1.276 & D 44\% \\
\hline $\begin{array}{l}\text { 29. If beginner students are permitted to make errors in English, it will } \\
\text { be difficult for them to speak correctly later. }\end{array}$ & 2.75 & .931 & N 50\% \\
\hline $\begin{array}{l}\text { 30. In learning English, it is important to practise with audio materials } \\
\text { (CDs, MP3s and etc.) }\end{array}$ & 3.94 & .772 & A $63 \%$ \\
\hline $\begin{array}{l}\text { 31. In learning English, it is important to practise by listening to TV, } \\
\text { Internet or radio programmes in English frequently }\end{array}$ & 4.06 & .680 & A 56\% \\
\hline
\end{tabular}
${ }^{*}$ S.A- Strongly agree; A-agree; N- neutral; D- disagree; S.D- strongly disagree

Table 4 reveals the responses of language beliefs in association to the learning and communication strategies. The results for this section seem to illustrate a mixture of positive and negative beliefs. A few of the positive outlooks are many of the 
respondents agreed that correct pronunciation is vital. They also acknowledged the significance of constant practice and repetition, and recognized the effectiveness of using a wide range of audio materials, mass media and the Internet so that they will become proficient English speakers. On the contrary, though many agreed that it is important to speak with excellent pronunciation, 44\% still agreed that they should not say anything in English until they can say it correctly. Besides that, some respondents exhibited shyness to speak English (36\% of agreement and strong agreement) while $44 \%$ disagreed. Generally, these results indicate that many respondents agreed that appropriate communicative activities are useful in enhancing their communication strategies: learning correct pronunciation, using authentic materials (audio, printed or online) and continuous practicing. Centre for Applied Linguistics (2015) also suggested that adult learners prefer authentic communication tasks and use communication strategies because they can acquire meaningful interaction and natural communication.

Table 5: Language Beliefs (Motivation and Expectations in ESL Learning)

\begin{tabular}{|c|c|c|c|}
\hline Items & Mean & Std. Deviation & $\begin{array}{c}\text { Highest } \\
\text { Frequencies }\end{array}$ \\
\hline 32. Malaysians feel that it is very important to learn English. & 4.06 & .854 & A / S.A $50 \%$ \\
\hline $\begin{array}{l}\text { 33. I would like to learn English so that I can get to know people who } \\
\text { speak English better (such as Americans, British or Australians). }\end{array}$ & 3.75 & .775 & A $56 \%$ \\
\hline $\begin{array}{l}\text { 34. If I can use English well, I will have better opportunities for a good } \\
\text { job. }\end{array}$ & 4.19 & .750 & $\begin{array}{l}\text { A } 44 \% \text { / S.A } \\
38 \%\end{array}$ \\
\hline 35. I want to be able to speak English well. & 4.06 & .574 & A 69\% \\
\hline 36. I would like to have friends from other countries. & 3.80 & .833 & A 44\% \\
\hline $\begin{array}{l}\text { 37. I want to learn English well because it can help me access } \\
\text { information from around the world. }\end{array}$ & 4.13 & .619 & A 63\% \\
\hline $\begin{array}{l}\text { 38. English is important for higher education level, especially diploma } \\
\text { and graduate studies. }\end{array}$ & 4.19 & .544 & A $69 \%$ \\
\hline $\begin{array}{l}\text { 39. Learning English will help me communicate with people from } \\
\text { other countries because English is an international language. }\end{array}$ & 4.25 & .577 & A $63 \%$ \\
\hline
\end{tabular}

${ }^{*}$ S.A- Strongly agree; A-agree; N- neutral; D- disagree; S.D- strongly disagree

The final set of items for language beliefs in relation to motivation and expectations revealed more positive responses as compared to the rests of the items. It is believed that the respondents were sufficiently motivated to acknowledge the significance of being good users of English language (most of the respondents agreed that English provides more opportunities for better careers, great access to information from all around the world, vital role for tertiary education and good communication with foreigners). Many adult learners are motivated to learn languages, especially if the activities involve communicative tasks such as solving problems or completing tasks that enables them to handle real-life tasks successfully (Condelli, Wrigley, \& Yoon, 2009; Miller, 2010; Peyton, Moore, \& Young, 2010; Wiggins \& McTighe, 2005). To add, they also agreed that communicating in English will enable them to expand their circle of friends and networking. Hence, with such positive responses, the respondents can improve their English proficiency and increase their confidence and motivation to learn the language. These results are parallel to the observations made by Smith and Strong (2009) who pointed out that most adult learners are goal-oriented and often direct their learning to fulfil specific needs.

\section{CONCLUSIONS AND RECOMMENDATIONS}

Learners' language beliefs have been regularly studied over the years in the area of education. These beliefs can actually affect one's drive and confidence to make an effort in learning a foreign language. The findings from the BALLI survey imply that these respondents who are adult learners possess both positive and negative beliefs, and the beliefs are at various levels. Notably, the inclination towards positive beliefs is seen to be stronger than the negative ones, especially the beliefs regarding foreign language learning / aptitude and, motivations and expectations in ESL learning. Perhaps, most adult learners are more target-driven and have obtained more experiences in which they are able to distinguish what they want to achieve in lives, as compared to the younger learners. Despite their individual differences, most adult learners are likely to be able to plan their own learning to suit their personal needs and preferences. In general, to improve the proficiency of the language learners, educators can plan and set up strategies which support learners of all age levels, who lack confidence and are weak in the language, to change their beliefs into more positive outcomes. Besides, to ensure a successful adult teaching and learning process, educators should be alert of what adult learners are expecting from their language lessons and what learning behaviours that they might bring into the classrooms. With such 
awareness, the educators can improve the way they teach language as to avoid impeding the adult learners' various learning beliefs, experiences and individualities. Furthermore, in tackling adult learners, the educators need to accept the reality that adult learners can learn a new language. Schleppegrell (1987) stated that the adult learners' self directness, life experiences, independence as learners, and motivations to learn should provide them with the advantages to learn as the ability to learn a language is not seen to decline with age.

\section{REFERENCES}

Brown, H.D. (2001). Teaching by principles: An interactive approach to language pedagogy. Second Edition. White Plains, NY: Pearson Education.

Burt, M., Peyton, J. K., \& Schaetzel, K. (2008). Working with adult English language learners with limited literacy: Research, practice, and professional development. Washington, DC: Center for Applied Linguistics. Retrieved from http://www. cal.org/caelanetwork/resources/limitedliteracy.ht $\mathrm{ml}$

Center of Applied Linguistics. (2015). Fundamental Principles of Effective Adult Language Education. Retrieved from: http://www.cal.org/adultesl/pdfs/fundamentalprinciples-of-effective-adult-languageeducation.pdf

Chew, F.P., \& Chui, J.H. (2012). Beliefs about ESL learning among secondary school students in Terengganu, Malaysia. International Journal of Research in Economics and Social Sciences, 2(2), 44-63.

Condelli, L., Wrigley, H., \& Yoon, K. S. (2009). "What works" for adult literacy students of English as a second language. In S. Reder \& J. Bynner (Eds.), Tracking adult literacy and numeracy skills: Findings from longitudinal research (pp. 132-159). New York and London: Routledge.

Dornyei, Z. (2005) The psychology of the language learner: individual differences in second language acquisition. Mahwah, NJ: Lawrence Erlbaum

Ellis, R. (2008) Learner Beliefs and Language Learning. Asian EFL Journal, 10(4), 7-25.

Ehrman, M. E., Leaver, B.L., \& Oxford, R. L. (2003). A brief overview of individual differences in second language learning. System, 31, 313-330.

Fazilatfar, A. M., Damavandi, R. R., Sani, R. H., \& Heirati, J. K. (2015). Learners' belief changes about language learning. International Journal of English Language Education, 3(1), 1-19.

Hurd, S. (2006) Individual learner differences and distance language learning: An overview. Retrieved from: http://oro.open.ac.uk/6002/1/IndLearnDiffsDLL100206.pdf
Hariati, A., \& Lee, Y.M. (2011). Top jobs only for those who know the language well. Retrieved August 7, 2014 from http://www.thestar.com.my

Horwitz, E.K. (1988). The beliefs about language learning of beginning university foreign language students. The Modern Language Journal, 72(3), 283-294.

Kalaja, P., \& Barcelos, A.M.F. (Eds.). (2003). Beliefs about SLA: New research approaches. Dordrecht: Kluwer Academic Publishers.

Kruidenier, J. (2002). Research-based principles for adult basic education reading instruction. Washington, DC: National Institute for Literacy. Retrieved February 8, 2005, from www.nifl.gov/partnershipforreading/publications/ html/adult ed/index.html

Merrit, A. (2013) Are children really better at foreign language. The Telegraph. Retrieved: 10 May 2014 from www.telegraph.co.uk/education/educationopinio $\mathrm{n} / 10315238$.

Miller, S. F. (2010). Promoting learner engagement when working with adult English language learners. Washington, DC: Center for Applied Linguistics. Retrieved from http://www.cal.org/adultesl/resources/digests/pro moting-learner-engagement-whenworking-withadult-english-language-learners.php

Nikitina, L., \& Furuoka, F. (2006) Re-examining Horwitz's Beliefs about Language Learning Inventory (BALLI) in the Malaysian context. Electronic Journal of Foreign Language Teaching, 3(2), 209-219.

Peyton, J. K., Moore, S. K., \& Young, S. (2010). Evidence-based, student-centered instructional practices. Washington, DC: Center for Applied Linguistics. Retrieved from http://www.cal.org/caelanetwork/resources/stude ntcentered.html

Richardson, V. (1996). The role of attitudes and beliefs in learning to teach. In J. Sikula, T.J. Butter \& E. Guyton (Eds.), Handbook of research on teacher education (pp.102-119). New York: Macmillan

Schleppegrell, M. (1987). The older language learner. ERIC Clearinghouse on Language and Linguistics Washington DC. Retrieved on: 11 June 2014 from www.ericdigests.org/pre927/older.htm

Smith, A.F.V., \& Strong, G. (2009). Adult language learners: An overview. Retrieved: 13 June 2014 from www.tesol.org/docs/bk CP AdultLL 615

Talebinejad, M. R., \& Nekouei, R. (2013). The relationship between foreign language anxiety and belief towards FLL among children EFL learners. Basic Research Journal of Education Research and Review, 2(3), 49-54.

Vilbulphol, J. (2004). Beliefs about language learning and teaching approaches of pre-service EFL Teachers in Thailand (Unpublished Dissertation). Oklahoma State University, USA. 
White, C. (2008). Beliefs and good language learners. In Griffiths, C. (Ed.), Lessons from good language learners (pp. 121-130). Cambridge University Press, Cambridge.

Wiggins, G., \& McTighe, J. (2005). Understanding by design. Alexandria, VA: Association for Supervision and Curriculum Development.

Woolfolk, A. E. (2006). Educational Psychology. Michigan: Allyn and Bacon.

Zuraidah, A. (2007). Willing learners yet unwilling speakers in ESL classrooms. Malaysian Journal of University Education, 3, 57. 